\title{
KNOWLEDGE AND ATTITUDE TOWARDS INFECTION CONTROL AMONG SUPPORTING STAFFS OF CHITWAN MEDICAL COLLEGE, BHARATPUR, CHITWAN \\ M Lopchan ${ }^{1 *}$, G Gurung ${ }^{1}$, L Rajbanshi ${ }^{2}$, C Osti $^{2}$, A Baniya $^{1}$ \\ ${ }^{1}$ College of Nursing, Chitwan Medical College, Bharatpur, Chitwan, Nepal ${ }^{2}$ Nursing Service Administration, Chitwan Medical College, Bharatpur, Chitwan, Nepal \\ *Correspondence to: Ms Milan Lopchan, College of Nursing, Chitwan Medical College, Bharatpur, Chitwan, Nepal. Email: lopchanm@gmail.com.
}

\begin{abstract}
Nosocomial infections (NIs) are one of the most important health issues, particularly in developing countries, because these infections cause high mortality and morbidity, and economic and human resource loss as a consequence Nosocomial infections can be defined as those occurring within 48 hours of hospital admission, 3 days of discharge or 30 days of an operation. Many studies have examined risk factors of nosocomial infections. However, knowledge of frontline workers (attendants) in infection prevention have been reported rarely in developing countries. The aim of this study was to investigate the knowledge of attendants working in different wards and OPDs about infection prevention. S: Data were collected from 100 attendants in Chitwan Medical College Teaching Hospital. Regarding the knowledge on hand washing, gloving and personal accessories for Infection Prevention, majority of the respondents had good knowledge ranging from 94-100\%. Though hospital has established Infection Prevention Committee and regular training on infection prevention is provided to all the staffs, the data indicated that only $68 \%$ respondents were benefitted by the infection prevention training and proper use of virex solution to disinfect the equipment's was found unsatisfactory. Infection control is the responsibility of all Health Care Facility (HCF) personnel. The goal of the infection control policies are to identify and reduce risks of acquiring and transmitting infections among patients, staff, students, volunteers, contract service workers, and visitors Although significant effort has been made to reduce the Nosocomial infections, regular training as well as monitoring supervision will enhance the capacity of the health care providers and front line workers for cleaning services they are our valued respondents.
\end{abstract}

Key words: Attitude, Infection Control, knowledge, Support staffs.

\section{INTRODUCTION}

Nepal is one of the least developed countries in South Asia. Health-care workers are at risk of contracting many diseases such as, hepatitis B (HBV), hepatitis $\mathrm{C}$ (HCV) human immune deficiency virus (HIV) and many more through exposure to blood and bodily fluids (BBF). It is estimated that between 600,000 and 1,000,000 episodes of mucous membrane exposure to BBF occur annually in the United Sates (US). Exposure to BBF is a serious occupational concern for health-care workers and represents a major risk of transmitting diseases. ${ }^{1}$ Hospitalacquired infections are caused by viral, bacterial, and fungal pathogens; the most common types are bloodstream infection (BSI), pneumonia (ventilatorassociated pneumonia [VAP]), urinary tract infection
(UTI), and surgical site infection (SSI). Nosocomial infections (NIs) are infections which result during treatment procedure in a hospital or a healthcare service unit. NIs are commonly known by the terms health care-associated or hospital-acquired infections (HAls). The best clinical care in the world can be worthless if patients pick up other infections while they are in the hospital. Hospital-associated infections (HAIs) also include occupational infections which occur among health care workers due to occupational hazards. 2 Healthcare-associated infections are recognized as a major burden for patients, society and healthcare managers. ${ }^{3}$ HAls not only constitute an important cause of morbidity, mortality, prolonged stay in the hospital and (C) 2016, JCMC. All Rights Reserved 
economic burden. However, it is directly related with the increased use of antibiotics and development of multidrug resistant microorganisms. ${ }^{4,5}$ Healthcare Associated Infections (HAls) has become a global medical challenge now a days. At any time, more than 1.4 million people worldwide acquire infectious complications in hospitals. ${ }^{6}$

A breach in infection control practices facilitates transmission of infection from patients to health care workers, other patients and attendants. ${ }^{7}$ It is therefore important for all health care workers to adhere to the infection control guidelines strictly. ${ }^{8}$ Cleaning certainly does play a role in preventing infections and saving lives. ${ }^{9}$ There is a significant variability in cleaning procedures between hospitals. Even within the hospitals, there is variability from person to person. Often under-recognized, hospital cleaning staffs are on the frontline of environmental disinfection, but they may not realize the importance of their role. ${ }^{10}$ Without protective practices such as antiseptic hand washing, the use of gloves, safe needles, sterile equipment, and safe instrument and waste disposal procedures outlined in universal precaution guidelines, health workers are at substantial risk of blood-borne infections. ${ }^{1}$ Identifying existing infection control knowledge, attitudes, and practices (KAP) among health care workers is a key step in developing a successful infection control program. ${ }^{12}$ Healthcare workers must know the various measures for their own protection. They should improve organization of work, implement standard precautions and dispose biomedical waste properly to prevent occupational exposure.

It is also the responsibility of institute itself to develop policies, procedures and activities which aim to prevent or minimize the risk of transmission of infectious disease at health care facilities and help in reducing the risk of health-care-associated infections (HAls) or nosocomial infections. Therefore, this study aimed to evaluate the knowledge and attitude of the cleaning staffs (attendants) towards Infection control measures in Chiwan Medical College Teaching hospital

\section{MATERIALS AND METHODS}

After getting ethical clearance from CMCInstitutional Review Committee, this study was conducted at Chitwan Medical College Teaching Hospital (CMCTH), Bharatpur-10, Chitwan, among one hundred attendants (Supporting Staffs) working in different department to find out their knowledge and attitude regarding Infection Control. All the supporting staffs working in $\mathrm{CMCTH}$ and willing to participate during the study period were included in this study through Purposive sampling technique. Informed consent was taken. Respondents who participated in this study were informed about the nature and purpose of the study. Privacy was maintained by using the code number. The Structured Administered Interview Questionnaire schedule was used to collect data from respondents. Content validity of the instrument was established by developing instrument on the basis of literature review and consulting with research committee members and subject experts $\mathrm{s}$. The collected data were checked, reviewed and organized for its accuracy and completeness. All the collected data were coded and analysed in SPSS program and calculated according to the nature of variables by using statistical techniques (frequency, percentage and mean). 


\section{RESULTS}

Table 1: Distribution of Respondents by working area, working experience, educational level and Infection Prevention training.

\begin{tabular}{|c|c|c|}
\hline Variables & $\begin{array}{l}\text { Frequency } \\
(n=100)\end{array}$ & $\%$ \\
\hline $\begin{array}{l}\text { Working area } \\
\text { - Wards } \\
\text { - OPDs }\end{array}$ & $\begin{array}{l}84 \\
16 \\
\end{array}$ & $\begin{array}{l}84 \\
16 \\
\end{array}$ \\
\hline $\begin{array}{l}\text { working experience } \\
\text { - Less than } 6 \text { months } \\
\text { - } 7 \text { months to } 12 \text { months } \\
\text { - } 13 \text { months to } 18 \text { months } \\
\text { - } 19 \text { months to } 24 \text { months } \\
\text { - More than } 24 \text { months }\end{array}$ & $\begin{array}{l}31 \\
17 \\
04 \\
08 \\
40\end{array}$ & $\begin{array}{l}31 \\
17 \\
04 \\
08 \\
40\end{array}$ \\
\hline $\begin{array}{l}\text { Educational level } \\
\text { - Illiterate } \\
\text { - Primary level } \\
\text { - Secondary level } \\
\text { - SIC and above }\end{array}$ & $\begin{array}{l}08 \\
51 \\
36 \\
05\end{array}$ & $\begin{array}{l}08 \\
51 \\
36 \\
05\end{array}$ \\
\hline $\begin{array}{l}\text { IP training } \\
\text { - Received } \\
\text { - Not received } \\
\text { Duration of training ( } n=68 \text { ) } \\
\text { - } 1 \text { day } \\
\text { - } 2 \text { days } \\
\text { - } 3 \text { days } \\
\text { - } 7 \text { days } \\
\text { - } 15 \text { days }\end{array}$ & $\begin{array}{l}54 \\
10 \\
1 \\
1 \\
2\end{array}$ & $\begin{array}{l}79.41 \\
14.71 \\
01.47 \\
01.47 \\
02.94\end{array}$ \\
\hline
\end{tabular}

Out of 100 respondents, majority (84\%) were working in inpatient departments (wards). Forty percent respondents had e working experience for more than 2 years. However, 31\% respondents had less than 6 months' working experience.. More than fifty percent $(51 \%)$ respondents reported that they had received primary level education. Similarly, 36\% respondents had SLC and above education. However, $8 \%$ respondents were found illiterate..

Regarding exposure to infection prevention training, about two thirds (68\%) respondents were exposed to training on Infection Prevention. Out of 68 respondents, ,79.41\% received training on infection prevention for only 1 day 10 respondents reported that they had training for 2 days and $5.88 \%$ respondents received same training for 3 days and more. (Table-1) 
Table 2: Respondents' knowledge on hand washing, gloving and personal accessories for Infection Prevention

\begin{tabular}{|c|c|c|}
\hline Variables & $\begin{array}{l}\text { Frequency } \\
(n=100)\end{array}$ & $\%$ \\
\hline \multicolumn{3}{|l|}{ Necessity of hand washing before and after any procedure } \\
\hline Yes & 94 & 94 \\
\hline No & 06 & 06 \\
\hline \multicolumn{3}{|l|}{ Necessity of wearing gloves while touching dirty materials } \\
\hline Yes & 100 & 100 \\
\hline No & 00 & 00 \\
\hline \multicolumn{3}{|l|}{ Necessity to take out dirty gloves before handling doors, windows \& other materials } \\
\hline Yes & 85 & 85 \\
\hline No & 15 & 15 \\
\hline \multicolumn{3}{|l|}{ Necessity to wear gloves while attending to cleaning process } \\
\hline Yes & 100 & 100 \\
\hline No & 00 & 00 \\
\hline \multicolumn{3}{|l|}{$\begin{array}{l}\text { Necessity to change the gloves for other procedure when you are in cleaning process } \\
\text { of wards }\end{array}$} \\
\hline Yes & 93 & 93 \\
\hline No & 07 & 07 \\
\hline \multicolumn{3}{|l|}{$\begin{array}{l}\text { Necessity to take out personal accessories like ring, bangles etc while working for } \\
\text { infection prevention }\end{array}$} \\
\hline Yes & 100 & 100 \\
\hline No & 00 & 00 \\
\hline
\end{tabular}

Regarding knowledge on hand washing, gloving and personal accessories for Infection Prevention, majority of the respondents (94\%) reported that hand washing is necessary before and after any procedure. $100 \%$ of the respondent reported gloving is necessary while touching dirty materials. $85 \%$ respondent reported it is necessary to take out gloves before handling doors, windows and other materials. All respondents reported gloving is necessary while attending to cleaning process. Similarly, $93 \%$ of the respondent reported gloves should be changed for other procedure when they are in cleaning process of the wards and $100 \%$ of the respondent reported personal accessories like ring, bangles etc. should be taken out while working for infection prevention. (Table-2) 
Table 3: Respondents' knowledge on cleaning process

\begin{tabular}{|c|c|c|}
\hline Variables & $\begin{array}{l}\text { Freque ncy } \\
(n=100)\end{array}$ & $\begin{array}{l}\text { Percentage } \\
(\%)\end{array}$ \\
\hline \multicolumn{3}{|c|}{ Frequency of time to clean floor in $\mathbf{2 4}$ hours } \\
\hline 1 time & 02 & 02 \\
\hline 2 times & 06 & 06 \\
\hline 3 times & 48 & 48 \\
\hline 4 times & 44 & 44 \\
\hline \multicolumn{3}{|c|}{ Amount of water to make 1 bottle of Virex $(160 \mathrm{gm})$} \\
\hline 6 liters & 04 & 04 \\
\hline 8 liters & 00 & 00 \\
\hline 10 liters & 93 & 93 \\
\hline 12 liters & 03 & 03 \\
\hline \multicolumn{3}{|c|}{ Time to immerged equipment's in virex solution for disinfection process } \\
\hline \multicolumn{3}{|l|}{$10 \mathrm{~min}$} \\
\hline $20 \mathrm{~min}$ & 82 & 82 \\
\hline $30 \mathrm{~min}$ & 15 & 15 \\
\hline \multirow[t]{2}{*}{$40 \min$} & 02 & 02 \\
\hline & 01 & 01 \\
\hline
\end{tabular}

Regarding knowledge on cleaning process, only $48 \%$ of respondents reported that hospital floor should be cleaned at least three times in 24 hours. 93\% of the respondents reported that virex $(160 \mathrm{gm})$ should be prepared in 10 liters of water and $82 \%$ of the respondents reported that used equipment's should be immersed 10 minutes in virex solution. (Table-3)

Regarding respondents' knowledge on refuse disposal, $88 \%$ of the respondent reported food material should be discarded in green container, $85 \%$ respondents reported that paper and plastic refuse are discarded in blue container, $96 \%$ respondents reported that blood contaminated refuse should be discarded in red container, only $43 \%$ respondents reported that for the final disposal, needles and sharp instruments should be discarded by taking to the collection container and $73 \%$ respondents reported each containers should be taken separately without mixing for the final disposal of the refuses. (Table-4) 
Table 4: Respondents knowledge on waste disposal

\begin{tabular}{|c|c|c|}
\hline Variables & $\begin{array}{l}\text { Frequency } \\
(n=100)\end{array}$ & Percentage (\%) \\
\hline \multicolumn{3}{|l|}{ color of container to discard food material } \\
\hline Red & 02 & 02 \\
\hline Green & 88 & 88 \\
\hline Blue & 09 & 09 \\
\hline Other & 01 & 01 \\
\hline \multicolumn{3}{|l|}{ color of container to discard paper and plastic } \\
\hline Red & 02 & 02 \\
\hline Green & 12 & 12 \\
\hline Blue & 85 & 85 \\
\hline Other & 01 & 01 \\
\hline \multicolumn{3}{|l|}{ color of container to discard blood contaminated refuse } \\
\hline Red & 96 & 96 \\
\hline Green & 00 & 00 \\
\hline Blue & 04 & 04 \\
\hline \multicolumn{3}{|l|}{ Final disposal of needles and sharp instruments } \\
\hline Taking from the collection container & 43 & 43 \\
\hline By transferring in another container from collection container & 25 & 25 \\
\hline By transferring in polythene bag from collection container & 32 & 32 \\
\hline \multicolumn{3}{|l|}{ Final disposal of all container's refuse } \\
\hline Each container separately & 73 & 73 \\
\hline By mixing all containers refuse in same container & 27 & 27 \\
\hline
\end{tabular}

\section{DISCUSSION}

HAls are the most common adverse events in hospitals, and the morbidity and mortality associated with them are significant. The Centers for Disease Control and Prevention (CDC) estimate that 1 out of every 25 hospitalized patients develop a healthcareassociated infection each year. In 2011, over 700,000 HAls occurred in U.S. hospitals, with 75,000 patients dying from complications of HAls. [12]

According to the findings of this study, majority of the attendants (48\%) have less than one year experience and only $68 \%$ of the attendants got training on Infection Prevention, where majority of them $(79.41 \%)$ had infection prevention training for only one day.. The findings of the study revealed that attendants (supporting staffs) do not have sufficient knowledge on Infection Prevention. The majority of the respondents did not give correct answer for frequency of floor cleaning and duration to immerse equipment's/ instruments in virex solution for 
disinfection process, only $15 \%$ of the attendants answered correctly. which was 20 minutes. Respondent demonstrated good knowledge on gloving, all the respondents reported correct responses for the gloving during cleaning process and dealing with patient care. Good knowledge was found regarding necessity of removing personal accessories like ring, bangles etc while working for infection prevention. Majority of the respondents had good knowledge regarding colour code for hospital refuse disposal. However, only $43 \%$ respondents demonstrated good knowledge regarding final disposal of the sharp instrument and needles and only 73\% reported that all containers' refuse should be carried out separately for the final disposal.

The increasing Prevalence of Hepatitis B, Hepatitis C and HIV and occupational transmission of infections can be halted through s compliance with universal precaution guidelines. Health-care institutions should provide a safe environment for caregivers by establishing or updating Infection Prevention policies and regular follow up. Strictly adopting all universal precautions is very important to protect all the health-care staff [1]. Hospital cleaners play a major role in creating and maintaining a safe and clean environment for the prevention of nosocomial infection. Continuing in-service education programs on infection control measures for hospital cleaners is recommended. Hospital cleaners should be trained yearly so as to be informed about infection control measures in their units of work [13].

\section{CONCLUSION}

Healthcare Associated Infections (HAls) has now become a global medical challenge $\&$ are recognized as a major burden for patients, society and healthcare management. Hospital cleaning staffs have also the important role in infection prevention as they are on the frontline of environmental disinfection \& cleaning services which certainly does play a pivotal role in preventing infections. Identifying existing infection control knowledge \& attitudes among health care workers is a key step in developing a successful infection control program. Every health care institution should develop policies, procedures and activities which aim to prevent or minimize the risk of transmission of infectious disease at health care facilities and help in reducing the risk of healthcare-associated infections (HAls) or nosocomial infections.

\section{ACKNOWLEDGEMENT}

Our gratitude and sincere thanks go to Prof. Dr. Harish Chandra Neupane, Chairman/ Managing Director of Chitwan Medical College and Dr. Gopendra Prasad Deo, Executive Editor of Journal of Chitwan Medical College (JCMC) for their encouragement and ever support for research activities at CMC. Similarly, Authors are grateful to all the nursing In charge of Chitwan Medical College Teaching Hospital (CMCTH) for their support \& respondents for their active participation in this study.

\section{REFERENCES}

1. Timilshina N, Ansari MA, Dayal V. Risk of infection among primary health workers in the Western Development Region, Nepal: knowledge and compliance. The Journal of Infection in Developing Countries. 2010 Aug 6;5(01):18-22.

2. Kelemua G, Gebeyaw T. Assessment of knowledge, attitude and practice of health care workers on infection prevention in health institution Bahir Dar city administration. Science Journal of Public Health. 2014;2(5):384-93.

3. World Health Organization. Practical guidelines for infection control in health care facilities. Manila: WHO Regional Office for the Western Pacific; 2004.

4. Lynch P, Pittet D, Borg MA, Mehtar S. Infection control in countries with limited resources. Journal of Hospital Infection. 2007 Jun 30;65:148-50.

5. Thu TA, Rahman M, Coffin S, Harun-Or-Rashid M, Sakamoto J, Hung NV. Antibiotic use in Vietnamese hospitals: A multicenter pointprevalence study. American journal of infection control. 2012 Nov 30;40(9):840-4.

6. http://www.infectioncontroltoday.com/

7. Sax H, Uçkay I, Richet H, Allegranzi B, Pittet D. Determinants of good adherence to hand hygiene among healthcare workers who have extensive exposure to hand hygiene campaigns.

(C) 2016, JCMC. All Rights Reserved 
Infection Control \& Hospital Epidemiology. 2007 Nov 1;28(11):1267-74.

8. Nazeera N, Taneepanichskul S, Najeeb N. Knowledge, attitude, and practice of standard and transmission-based precautions in tertiary and secondary health care settings of Maldives/ Nazeera Najeeb.

9. Dancer SJ. The role of environmental cleaning in the control of hospital-acquired infection. Journal of hospital Infection. 2009 Dec 31;73(4):378-85.

10. Tara Palmore, MD, deputy hospital epidemiologist at the NIH Clinical Center. Infection control in hospitals: The role of environmental disinfection. Infectious Disease News, March 2014.
11. Tenna A, Stenehjem EA, Margoles L, Kacha E, Blumberg HM, Kempker RR. Infection control knowledge, attitudes, and practices among healthcare workers in Addis Ababa, Ethiopia. Infection Control \& Hospital Epidemiology. 2013 Dec 1;34(12):1289-96.

12. Infection Control. Available at : http://www. nursingceu.com/courses/485/index_nceu.html

13. Mothiba T, Maputle S. Knowledge and Practices of Infection Control Interventions amongst Hospital Cleaners at Health Care Units of Capricorn District, Limpopo Province. 